\title{
TEMPERATE ICE BENEATH THE “POLAR" TAYLOR GLACIER, VICTORIA LAND, ANTARCTICA (Abstract only)
}

\author{
by \\ P. H. Robinson* \\ (Antarctic Research Centre, Department of Geology, Victoria University of Wellington, Wellington, \\ New Zealand
}

ABSTRACT

Two interdependent lines of evidence contribute to an understanding of basal ice conditions within Taylor Glacier, from the thermal regime and from features of the englacial and basal debris. The thermal regime of the basal ice in Taylor Glacier suggests mechanisms for the entrainment and transportation of debris near the glacier sole.

Assuming steady-state conditions, basal temperatures over the ablation area of Taylor Glacier were calculated from the geothermal heat influx, the nearsurface ice temperatures, ice velocities, and the ice thickness. In over $50 \%$ of the lower ablation area the basal ice may be melting.

The englacial and basal debris is incorporated by processes operating at the glacier sole. Englacial debris is incorporated by particle regelation; basal debris is incorporated by freezing block regelation. Both processes occur close to the glacier margin, where inner warm basal ice is in contact with marginal cold ice. The debris frozen to the sole here remains relatively unmodified during transport to the margin. Both lines of evidence indicate that Taylor Glacier is, and has been, capable of erosion and entrainment of debris by temperate ice at the glacier sole. Debris deposited along the margin is similar to drift deposited beyond the glacier, implying that any recent climatic changes have had little effect on basal ice conditions within Taylor Glacier.

* Present address: Alpine Processes Group, Water and Soil Division, Ministry of Works and Development, Christchurch, New Zealand.

\section{RADIO ECHO-SOUNDING OF RIISER-LARSENISEN* (Abstract only)}

by

\section{Olav Orheim}

(Norsk Polarinstitutt, Postboks 158, 1330 Oslo Lufthavn, Norway)

ABSTRACT

The Norwegian Antarctic Research Expedition 1978-79 used the Scott Polar Research Institute Mk IV radio echo-sounding system fitted in a Bell $206 \mathrm{~B}$ helicopter to survey $620 \mathrm{~km}$ of Riiser-Larsenisen and $100 \mathrm{~km}$ across the outer part of Stancomb-Wills Ice Stream. Observed thicknesses of Riiser-Larsenisen decrease from $700 \mathrm{~m}$ at the grounding line to less than $200 \mathrm{~m}$ at the ice front. The thickness of $B 1$ a enga ice rise varied between 200 and $450 \mathrm{~m}$. The ice shelf thins towards the east, and seems there to flow obliquely to the ice front (Fig.1).

Step-like change in thickness of $>150 \mathrm{~m}$ over $500 \mathrm{~m}$ horizontal distance is observed in the central part of the ice shelf. The records also demonstrate undulations in ice thickness of 600 to $700 \mathrm{~m}$ wavelength and $50 \mathrm{~m}$ amplitude, and various types of rifts and crevasses. Internal layering is recorded at 250 to $300 \mathrm{~m}$ depth over B 1 laenga and in the ice shelf up-stream of this ice rise.

Observed ice thicknesses on Stancomb-Wills Ice Stream range from 130 to $220 \mathrm{~m}$, with no systematic decrease towards the ice front. The records include long sections of heavy scatter from densely spaced rifts and bottom crevasses. This ice stream attains velocities $>4 \mathrm{~km} \mathrm{a}^{-1}$, and is much more active than Riiser-Larsenisen. This high activity has resulted in extensive fracturing of the ice shelf.

Fig.1. Ice thickness of Riiser-Larsenisen. Short dashes mark the grounding line and the boundary of the ice rise, as determined from Landsat imagery.

*Norsk Polarinstitutt Contribution No.213.

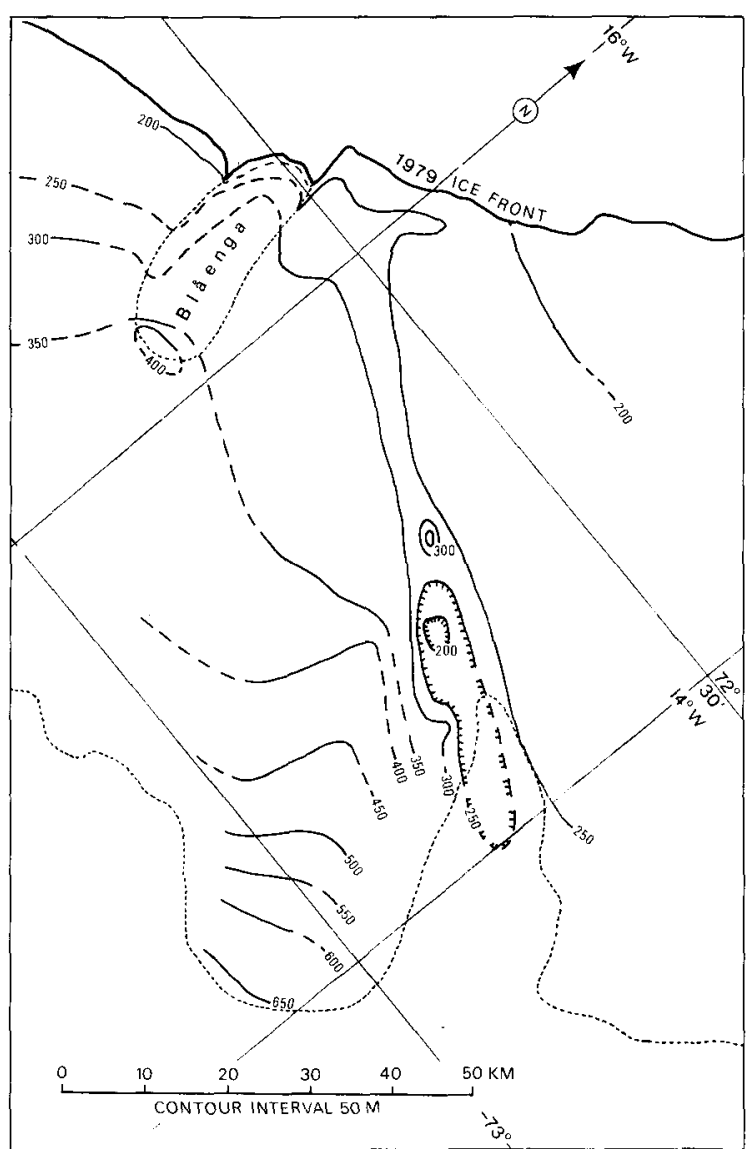

